\title{
ANALISIS TINGKAT KEBAHAGIAN MAHASISWA JURUSAN PENDIDIKAN AGAMA KRISTEN
}

\author{
Lasmaria Lumban Tobing $^{1 *}$, Masniar Hernawaty Sitorus ${ }^{2)}$, \\ Elvri Teresia Simbolon ${ }^{3)}$, dan Megawati Manullang ${ }^{4)}$ \\ ${ }^{1)}$ Prodi Manajemen Pendidikan Kristen, Institut Agama Kristen Negeri Tarutung \\ ${ }^{2)}$ Prodi Pendidikan Agama Kristen, Institut Agama Kristen Negeri Tarutung \\ ${ }^{3)}$ Prodi Sosiologi Agama, Institut Agama Kristen Negeri Tarutung \\ ${ }^{4)}$ Prodi Teologi, Institut Agama Kristen Negeri Tarutung
}

\begin{abstract}
This study aims to find out to what extent of the percentage analysis of the level of students' happiness in their life processes. The research method used is descriptive quantitative and inferential research. The population of this study were all students of the department of Christian religious education IAKN Tarutung which were 566 students. The sample in the study was 86 people who were randomly assigned. The research instrument was a closed questionnaire with four options. Data analysis techniques using the t-test. Based on the analysis it is known that the level of student happiness is $78.45 \%$ in the good category. From the results of the hypothesis test that the t-test $=13.251$ and the table is 1.684 , where t-count $>t$-table is 13.251>1.684. Thus it can be concluded that the analysis of the happiness level of Deparment PAK IAKN Tarutung students in 2019 in their life processes is $\geq 75 \%$ of what was expected.
\end{abstract}

Keywords: Happiness, student college, Christian religious education

\begin{abstract}
ABSTRAK
Penelitian ini bertujuan untuk mengetahui seberapa besar persentase analisis tingkat kebahagiaan mahasiswa dalam proses kehidupannya. Metode penelitian yang dipakai adalah penelitian kuantitatif deskriptif dan inferensial. Populasi penelitian ini adalah seluruh mahasiswa Jurusan PAK IAKN Tarutung sebanyak 566 orang. Sampel dalam penelitian 86 orang yang ditetapkan secara acak. Instrumen penelitian ini berupa angket tertutup dengan empat option. Teknik analisis data dengan menggunakan uji t. Berdasarkan hasil analisis diketahui bahwa tingkat kebahagiaan mahasiswa adalah 78,45 \% berada dalam kategori baik; Dari hasil uji hipotesa bahwa uji $\mathrm{t}_{\text {hitung }}=13,251$ dan $\mathrm{t}_{\text {tabel }}$ yaitu 1,684 , dimana $t_{\text {hitung }}>t_{\text {tabel }}$ yaitu $13,251>1,684$. Dengan demikian, dapat disimpulkan bahwa hasil penelitian ini menunjukkan bahwa analisis tingkat kebahagiaan mahasiswa Jurusan PAK IAKN Tarutung Tahun 2019 dalam proses kehidupannya adalah $\geq 75 \%$ dari yang diharapkan.
\end{abstract}

Kata Kunci: Kebahagian, mahasiswa, pendidikan agama Kristen

1 | Korespondensi mengenai artikel dapat dilakukan kepada: Lasmaria Lumban Tobing, Prodi Manajemen Pendidikan Kristen, Institut Agama Kristen Negeri Tarutung, Jl. Raya Tarutung-Siborong KM 11, Silangkitang, Sipoholon, Tapanuli Utara (22452), Indonesia

E-mail Corresponding: lasmarialumbantobing@gmail.com 


\section{PENDAHULUAN}

Manusia adalah makhluk yang paling istimewa dibandingkan dari seluruh ciptaan Tuhan. Manusia memiliki akal dan pikiran yang membedakannya dari ciptaan lain. Dengan kekuatan tersebut, manusia dapat mencapai perubahan yang signifikan dalam kehidupannya.

Berbagai penemuan, inovasi, teknologi, ideologi, sarana hiburan, dan lainlain, yang diciptakan manusia adalah pencapaian manusia yang memungkinkan manusia itu sendiri untuk lebih baik dari sebelumnya. Tak dapat dipungkiri bahwa semua itu dilakukan memberikan berbagai dampak bagi manusia, salah satunya adalah dampak kebahagiaan.

Semua manusia pasti ingin bahagia. Kebahagiaan merupakan suatu keadaan pikiran atau perasaan yang ditandai dengan kecukupan hingga kesenangan, cinta, kepuasan, kenikmatan, atau kegembiraan yang intens. Kebahagiaan memberikan dampak positif dalam segala aspek kehidupan dan akan mengarahkan pada hidup yang lebih baik, misalnya memberikan kita kesempatan untuk menciptakan hubungan yang lebih baik, menunjukkan produktifitas yang lebih besar, memiliki umur yang lebih panjang, kesehatan yang lebih baik, kreativitas yang lebih tinggi dan kemampuan pemecahan masalah dan membuat keputusan mengenai rencana hidup dengan lebih baik.

Kebahagiaan datang melalui banyak jalan. Dengan memegang pandangan ini dapat dipahami bahwa menjaga tugas hidup masing-masing adalah untuk mengatur kekuatan dan kebijakan pribadi masing-masing dalam wilayah-wilayah utama kehidupan, seperti pekerjaan, cinta, pengasuh anak, dan pencarian tujuan hidup. Kebahagiaan dapat dicapai melalui hal-hal yang disukai oleh pribadi tertentu.

Kebahagiaan pada mahasiswa dapat diperoleh melalui pemenuhan kebutuhan serta tugas perkembangannya. Mahasiswa yang bahagia adalah mahasiswa yang mampu menerima segala apa yang dimiliki dengan emosi yang positif. Selain itu, mahasiswa yang bahagia merupakan individu yang mampu menyesuaikan diri dengan dirinya sendiri serta lingkungan. Sehingga mahasiswa mampu menempatkan diri antara kebutuhan dengan harapan yang ada. Mahasiswa sebagai individu dewasa dini berada pada masa transisi dari masa remaja dan dewasa. Pada masa transisi ini mahasiswa dihadapkan oleh banyak perubahan yang dapat mengganggu upaya untuk mendapatkan kebahagiaan. Oleh sebab itu, mahasiswa harus mampu menyesuaikan diri terhadap segala perubahan di lingkungan. Individu yang mampu menyesuaikan diri dan mampu berinteraksi dengan baik pada akhirnya mempengaruhi kebahagiaan pada masa dewasa dini.

Untuk mendapatkan suatu perasaan yang bahagia, tak jarang individu melakukan berbagai cara. Pada kenyataannya individu menginginkan emosi positif, namun sering memilih jalan pintas yang tak terhingga banyaknya untuk merasa bahagia, seperti melalui narkotika, cokelat, seks tanpa cinta, berbelanja, 
masturbasi, dan televisi. Kebahagiaan yang diperoleh dengan cara tersebut hanya bersifat sementara, sehingga tidak akan menimbulkan kebahagiaan yang seutuhnya. Kegiatan-kegiatan tersebut menimbulkan ketergantungan atau bahkan dapat menimbulkan depresi.

Kebahagiaan sebagai emosi positif yang didapat melalui jalan pintas akan mengurangi nilai kebahagiaan itu sendiri. Jalan pintas tersebut membuat individu menjadi pribadi yang lain. Seperti yang diungkapkan oleh Seligman (2005:10) yaitu "jika emosi positif yang terpisah dari penggunaan karakter akan mengarah pada kepalsuan, kehampaan, depresi dan sejalan dengan semakin menuanya manusia, ada kesadaran yang mengusik hati yaitu berupa kegelisahan sepanjang hayat manusia". Kebahagiaan yang semu tersebut dapat mengakibatkan kegelisahan bagi individu dalam menjalani kehidupan.

Ketidakbahagiaan dapat menimbulkan hancurnya penyesuaian diri baik secara sosial maupun pribadi (Hurlock, 2012). Individu yang kurang bahagia memiliki penilaian yang negatif mengenai diri maupun kepada orang yang ada di sekitarnya. Oleh sebab itu individu yang kurang bahagia memiliki penyesuaian diri yang kurang baik. Apabila hal tersebut terus terjadi, maka individu dapat mengalami kegagalan tugas perkembangan, khususnya pada aspek pribadi dan sosialnya.

Mahasiswa IAKN Tarutung adalah dalam kategori dewasa dini (18-40 Tahun). Pada masa dewasa dini, mahasiswa akan dihadapkan dengan dunia baru serta masalah-masalah baru yang mengikutinya. Pada tahap ini mahasiswa telah dianggap mampu mengambil keputusan untuk masa depannya. Mahasiswa juga seharusnya telah mampu mengetahui kemampuan dan tanggungjawab yang harus dipikulnya. Dari hasil pengamatan peneliti, masih ditemukan mahasiswa yang kurang bahagia, seperti mahasiswa yang mengalami kecemasan akan masa depan akibat mengalami salah memilih jurusan, sehingga ketika perkuliahan mahasiswa merasa kurang serius.

Dalam memilih jurusan, diketahui ada mahasiswa yang memilih jurusan karena dorongan orangtua atau orang lain yang berpengaruh dalam hidupnya, bukan karena keinginan sendiri atau karena merupakan cita-cita mahasiswa itu sendiri. Hal tersebut menandakan bahwa mahasiswa masih ada yang belum mampu menentukan jalan hidupnya, sehingga mahasiswa tersebut mengalami kecendrungan tidak bahagia. Selain itu terdapat pula mahasiswa yang mengalami kurang konsentrasi karena merasa jauh dari rumah, sehingga kegiatan yang dilakukan cenderung kurang maksimal yang mengakibatkan munculnya kekhawatiran yang berlebihan. Selain itu, ada juga mahasiswa yang mengaku sering dimarahi orang tua karena jarang pulang. Hal tersebut dikarenakan mahasiswa tersebut lebih merasa bahagia bersama dengan teman-temannya.

3 | Analisis Tingkat Kebahagian Mahasiswa Jurusan Pendidikan Agama Kristen..., Lumban Tobing, dkk Jurnal Christian Humanioran | http://e-journal.iakntarutung.ac.id/index.php/humaniora 
Masalah pada mahasiswa tersebut di atas merupakan bentuk ketidakmampuan dalam menyelesaikan masalah yang memunculkan perasaan kurang bahagia, sehingga berpengaruh terhadap kehidupan yang sedang dijalaninya. Semakin banyak masalah yang tidak mampu diselesaikan, maka semakin rendah tingkat kebahagiaan yang akan dirasakan mahasiswa. Mahasiswa yang gagal dalam menentukan jalan kehidupannya dan kurang siap menerima tanggung jawab mengakibatkan kurangnya kebahagiaan yang dirasakan. Kurangnya kebahagiaan pada mahasiswa dapat mengganggu ketercapaian tugas perkembangan, khususnya pada aspek pribadi dan sosialnya.

Dengan demikian peneliti bertujuan ingin mengetahui persentase tingkat kebahagiaan mahasiswa Jurusan PAK IAKN Tarutung, sehingga dapat bagaimana keadaan mahasiswa sekarang ini. Dengan demikian, penelitian diharapkan dapat memberikan masukan pada institusi IAKN Tarutung dalam mengarahkan dan membina mahasiswa IAKN Tarutung khususnya Jurusan PAK ke arah yang lebih baik.

\section{METODE PENELITIAN}

Metode penelitian yang digunakan adalah jenis kuantitif dengan data deskriptif dan statistik inferesial. Sugiyono (2010:147) mengemukakan bahwa "statistik inferensial adalah tehnik statistik yang digunakan untuk menganalisa data sampel dan hasilnya diberlakukan untuk populasi". Berdasarkan pendapat tersebut, maka penelitian ini menggunakan penelitian kuantitatif dengan analisis data deskrifitif dengan statistik inferensial. Berdasarkan paparan dalam pendahuluan, peneliti ingin mengetahui persentase tingkat kebahagiaan mahasiswa dalam proses kehidupannya.

Penelitian ini dilakukan di IAKN Tarutung Silangkitang Kecamatan Sipoholon. Waktu penelitian dilaksanakan pada bulan Agustus-Nopember Tahun 2019. Bambang Prasetyo (2009:19), menerangkan bahwa "populasi adalah keseluruhan gejala yang akan diteliti”. Berdasarkan pendapat tersebut populasi dalam penelitian ini adalah seluruh Mahasiswa Jurusan PAK IAKN Tarutung Tahun 2019 sebanyak 566. Selanjutnya, menurut Arikunto (2002), apabila subjeknya kurang dari 100 orang, lebih baik diambil semua, sehingga penelitian ini merupakan penelitian populasi, selanjutnya jika jumlahnya lebih dari 100 orang maka jumlah sampel dapat diambil antara $10-15 \%$ atau $20-25 \%$ atau lebih." Berdasarkan pendapat di atas, maka peneliti menarik sampel penelitian adalah 15\% dari seluruh Mahasiswa Jurusan PAK IAKN Tarutung Tahun 2019 sebagai berikut.

Teknik pengumpulan data dalam penelitian ini menggunakan angket tertutup dengan prosedur sebagai berikut yaitu memberi pengarahan agar mereka dengan jujur menjawab pertanyaan yang ada, Menyebarkan angket pada responden, memberi tanda lingkaran (O) atau silang (x) untuk setiap jawaban 
pada item, dan mengumpulkan semua hasil angket dan dicatat ke dalam tabel distribusi angket.

Teknik analisa data merupakan syarat mutlak dalam setiap penelitian untuk menuju kebenaran hipotesis yang telah dirumuskan sebelumnya. Untuk membuktikan apakah hipotesis yang telah dirumuskan oleh peneliti apakah diterima atau ditolak, maka dilakukan pengolahan data dengan menganalisis data jawaban dari responden dengan menggunakan langkah-langkah sebagai berikut: (1) melakukan pendistribusian berdasarkan alternatif jawaban sesuai dengan bobot yang telah ditentukan dan mentabulasikan jawaban responden sesuai dengan bobot atau jawaban yang telah ditentukan menurut option yang telah ditentukan, (2) melakukan analisis data dengan menggunakan t-test satu sampel (Sugiyono, 2010:178); (3) mendeskripsikan hasil analisis data, dan (4) melakukan uji hipotesa :

Hipotesa Statistik dinyatakan dengan:

Ha $: t_{\mathrm{h}}>\mathrm{t}_{\mathrm{t}} ; 0,05$

Ho: $\mathrm{t}_{\mathrm{h}}<\mathrm{t}_{\mathrm{t}} ; 0.05$

Ha : Jika $t_{\text {hitung }}>t_{\text {tabel }}$ artinya analisis tingkat kebahagiaan mahasiswa $\geq 75$ $\%$ dari yang diharapkan.

Ho : Jika $t_{\text {hitung }}<\mathrm{t}_{\text {tabel }}$ artinya artinya analisis tingkat kebahagiaan mahasiswa $\leq 75 \%$ dari yang diharapkan.

\section{HASIL DAN PEMBAHASAN}

Berdasarkan hasil analisis penelitian didapat Persentase tingkat kebahagiaan Mahasiswa Jurusan PAK IAKN Tarutung Tahun 2019 dalam proses kehidupannya seperti yang ditampilkan pada Gambar 1.

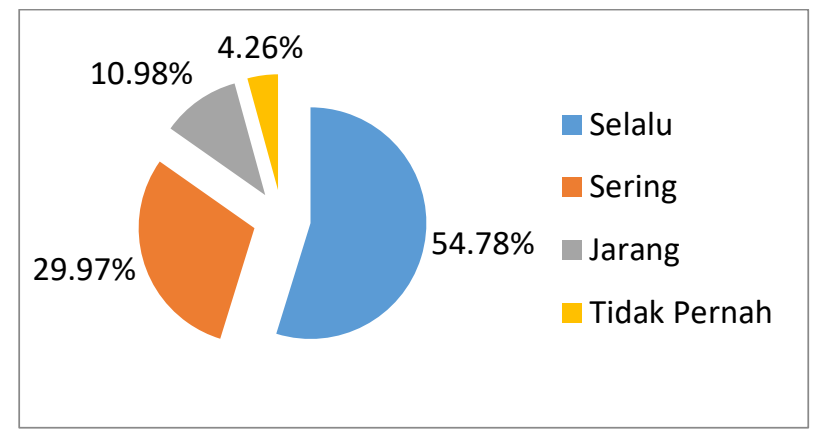

Gambar 1. Persentase tingkat kebahagiaan Mahasiswa

Adapun persentase tingkat kebahagiaan mahasiswa Jurusan PAK IAKN Tarutung Tahun 2019 dalam proses kehidupannya secara umum diketahui 54,78\% Selalu Bahagia; 29,97 \% Sering Bahagia, 10,98 \% Jarang Bahagia, 4,26\% Tidak Pernah Bahagia.

5 | Analisis Tingkat Kebahagian Mahasiswa Jurusan Pendidikan Agama Kristen ..., Lumban Tobing, dkk Jurnal Christian Humanioran | http://e-journal.iakntarutung.ac.id/index.php/humaniora 
Persentase tingkat kebahagiaan berdasarkan indikator penelitian, Mahasiswa Jurusan PAK IAKN Tarutung Tahun 2019 dalam proses kehidupannya ditampilkan pada Gambar 2.

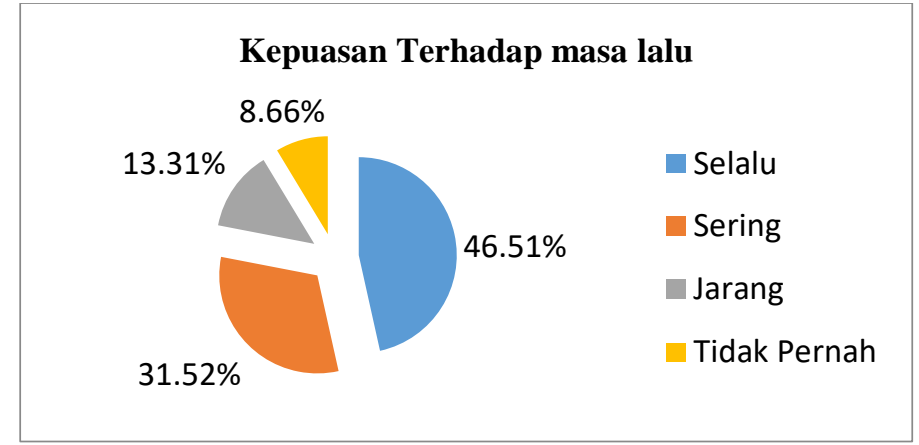

Gambar 2. Kepuasan terhadap masa lalu

Indikator penelitian kepuasan terhadap masa lalu diketahui bahwa 46,51\% Selalu Puas terhadap masa lalu, 31,52 \% Sering Puas terhadap masa lalu, 13,31\% Jarang Puas terhadap masa lalu, 8,66\% Tidak Pernah puas dengan masa lalu;

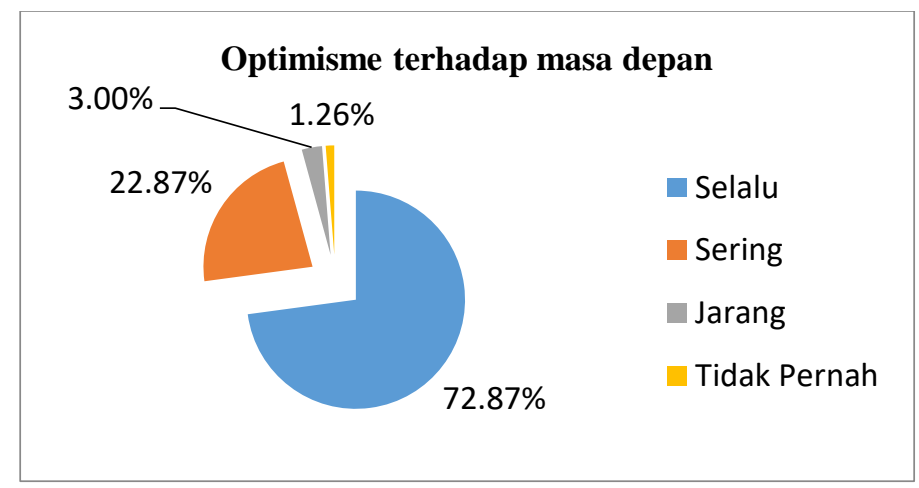

Gambar 3. Optimisme terhadap masa depan

Terkait kebahagian mahasiswa dapat dilihat pada Gambar 4. Indikator penelitian optimisme terhadap masa depan diketahui bahwa 72,87\% Selalu Bahagia; 22,87\% Sering Bahagia, kemudian 3,00 \% Jarang Bahagia; 1,26\% Tidak Pernah Bahagia dengan optimisme terhadap masa depan.

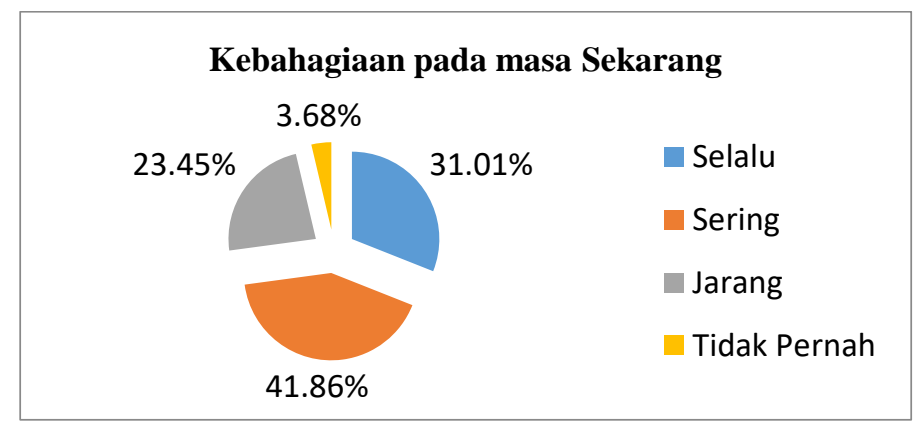

Gambar 4. Kebahagian pada masa sekarang

6 | Analisis Tingkat Kebahagian Mahasiswa Jurusan Pendidikan Agama Kristen..., Lumban Tobing, dkk Jurnal Christian Humanioran | http://e-journal.iakntarutung.ac.id/index.php/humaniora 
Indikator penelitian kebahagiaan pada masa sekarang diketahui bahwa 31,01\% Selalu Bahagia dengan keadaannya sekarang; 41,86\% Sering Bahagia dengan keadaannya sekarang, kemudian 23,45 \% Jarang Bahagia dengan keadaannya sekarang; 3,68\% Tidak Pernah Bahagia dengan keadaannya sekarang.

Persentase hasil penelitian adalah 78,45 \% mahasiswa merasa bahagia, dan sisanya merasa tidak bahagia; Dari hasil uji hipotesa bahwa uji $t_{\text {hitung }}=13,251>$ $t_{\text {tabel } 86-1, \alpha=5 \%}$ yaitu 1,684 , dimana $t_{\text {hitung }}>t_{\text {tabel }}$ yaitu $13,251>1,684$. Dengan demikian Ha diterima dan Ho ditolak. Dengan demikian dapat disimpulkan bahwa Analisis tingkat kebahagiaan mahasiswa Jurusan PAK IAKN Tarutung Tahun 2019 dalam proses kehidupannya adalah $\geq 75 \%$ dari yang diharapkan. Hasil penelitian ini menyimpulkan bahwa analisis Tingkat Kebahagiaan Mahasiswa Jurusan Pendidikan Agama Kristen IAKN Tarutung 2019 dalam proses kehidupannya adalah $\geq 75 \%$ dari yang diharapkan yaitu sebesar 78,45\%. Dengan demikian Ho ditolak dan Ha diterima.

\section{KESIMPULAN DAN SARAN}

Kebahagiaan merupakan kemampuan menata emosi, sehingga berpikir positif, bertindak bekerja dengan positif dengan indikator kepuasan pada masa lalu, optimisme pada masa depan dan kebahagiaan pada masa sekarang. Setiap orang merupakan penilai utama mengenai kebahagiaan yang mereka rasakan, karena mereka adalah pihak yang terlibat langsung dengan proses pencapaian kebahagiaan dalam hidupnya, sehingga ketika mereka merasakan kebahagiaan tersebut maka merekalah yang dapat menilai dan mendeskripsikannya secara tepat. Dalam mencapai kebahagiaan sendiri manusia mempunyai cara yang berbeda-beda antara individu yang satu dengan yang lainnya. Oleh karena cara untuk mencapainya berbeda-beda, emosi positif menjadi tiga macam yaitu emosi positif yang ditujukan pada masa lalu, masa depan dan masa sekarang.

Berdasarkan hasil penelitian bahwa $t_{\text {hitung }}=13,251>t_{\text {tabel } 86-1, \alpha=5 \%}$ yaitu 1,684 , dimana $t_{\text {hitung }}>t_{\text {tabel }}$ yaitu 13,251 $>1,684$. Dengan demikian Ha diterima dan Ho ditolak. Dengan demikian dapat disimpulkan bahwa Analisis tingkat kebahagiaan mahasiswa Jurusan PAK IAKN Tarutung Tahun 2019 dalam proses kehidupannya adalah $\geq 75 \%$ dari yang diharapkan atau sudah baik. Berdasarkan hasil penelitian bahwa analisis tingkat kebahagiaan mahasiswa Jurusan PAK IAKN Tarutung Tahun 2019 dalam proses kehidupannya adalah $\geq 75 \%$ dari yang diharapkan.

Perbaikan layanan kampus bagi mahasiswa menjadi sebuah kebutuhan yang tidak dapat dipisahkan. Peningkatan kebahagian mahasiswa dapat dilakukan dengan pelayanan yang penuh kasih oleh dosen dan tenaga kependidikan dalam proses pendidikan mahasiswa selama di kampus.

7 | Analisis Tingkat Kebahagian Mahasiswa Jurusan Pendidikan Agama Kristen..., Lumban Tobing, dkk Jurnal Christian Humanioran | http://e-journal.iakntarutung.ac.id/index.php/humaniora 


\section{DAFTAR PUSTAKA}

. 2010. Alkitab. Jakarta : Lembaga Alkitab Indonesia

Arikunto, S. 2002. Prosedur Penelitian. Jakarta: Rineka Cipta.

Astuti, H. 2007. Psikologi perkembangan Dewasa. Surabaya: Usaha Nasional

Prasetyo, B. \& Jaannah, L. M. 2009. Metode Penelitian Kuantitatif: Teori dan Aplikasi. Jakarta: PT. RajaGrafindo Persada.

Carr, A. 2004. Positive Psychology. The Science of Happiness and Human Strengths. New York: Brunner Routledge.

Kartono, K. 1990. Pengantar Metodologi Riset Sosial. Bandung: Bandar Maju.

Hurlock, E. B. 2012. Psikologi Perkembangan. Suatu Pendekatan Sepanjang Rentang Kehidupan. Jakarta: Erlangga.

Santrock, J. W. 2002. Psikologi Pendidikan. Jakarta: Predana Media Group

Sarwono, S. 1994. Psikologi Remaja. Jakarta: Raja Grafindo.

Schultz, D. 2005. Psikologi Pertumbuhan. Yogyakarta: Kanisius

Seligman E. P. 2005. Authentic Happiness. Bandung: Mizan Pustaka.

Steinberg, L. 1997. Adolescence ninth edition. Philadelphia: McGrawHill.

Sugiyono, S. 2010. Metode Penelitian Pendidikan (Pendekatan Kuantitatif, Kualitatif, dan $R \& D$ ). Bandung: Alfabeta. 